\title{
TYPOLOGICAL ANALYSIS OF HOUSING DEVELOPMENT IN LAGOS PERI-URBAN
}

\author{
Adedire Funmilayo Mokunfayo* \\ Adebamowo Michael** \\ Iweka Anthony***
}

\begin{abstract}
This research examines the typological analysis of housing development in the peri-urban settlements of Lagos State, Nigeria. Case study methodology was adopted, using random sampling to select housing developments under different housing initiatives, in purposely selected peri-urban settlements in Ibeju-Lekki Local Government Area of Lagos State. Primary data collection was from survey questionnaires, direct observations and in-depth interviews administered to household heads in the case study area. Data analysis was done using descriptive statics to generate frequencies, percentages, cross tabulations of the variables. Findings showed different housing typologies under three categories: owner occupied, part rental and full rental housing. Housing typologies in the study area were influenced by different housing initiatives, and the socio-economic attributes of the residents revealed a heterogeneous mix of the population in terms of culture, literacy level and household size. Based on the research findings it is recommended that the residents' socio-demography should be put into consideration in building typology designs, to enhance effective user performance in peri-urban housing development under diverse housing development schemes in Lagos State.
\end{abstract}

Keywords: Peri-Urban, Housing Typology, Architecture, Socio-Demography, Housing Initiatives

\section{INTRODUCTION}

Housing typologies in the emerging peri-urban settlements in Lagos, Nigeria are a product of many factors, often not perfectly meeting the required needs of the end users. The complexity of the relationship between different actors in the peri-urban areas is giving rise to a new urbanism, which if not controlled may lead to poor housing performance in the region. Presently, the peri-urban areas in Lagos play a significant role in housing a big percentage of the urban population. Different housing initiatives are emerging with diverse housing architecture having unsustainable designs. Government participation in housing is perceived to be illconceived, because post occupancy evaluations have proven many housing typologies adopted are failing to meet the user needs.

The predominant housing development in the peri-urban areas is executed through self-help housing which leaves design within the control of the households. The rising demand for housing and increased preference for single family houses is the major driver of self-help housing development in peri-urban settlements in developing countries (Gough and Yankson, 2000). Individual household take responsibility for the construction of their housing units and are associated with self-help housing development through non-customized and standardised architectural designs which impact the typology of housing. Family financial status is the key in the housing typology to be adopted. This is the premises for self-help housing development in most of the peri-urban areas of Lagos.

The private developer-led housing development is unique because it is formally regulated and is predominantly occupied by middle class and higher income migrants from the city centres (Simon, 2008). According to Marxist or radical theory, housing is seen having use value and exchange and as a product whose consumption can only be realized by those with a housing need and those who can afford it. It encourages and fosters the exploitation by bodies like private

* Dr. Adedire Funmilayo Mokunfayo, Research Assistant, Department of Architecture, University of Lagos, Nigeria.

Email Correspondence: funmidire@gmail.com

** Adebamowo Michael, Professor, Department of Architecture, University of Lagos, Nigeria.

Email correspondence: michaeladebamowo@yahoo.com

*** Dr. Iweka Anthony, Senior Lecturer, Department of Architecture, University of Lagos, Nigeria.

Email correspondence: tonyiweka@yahoo.com 
developer, often engaging in mostly unaffordable and unsuitable housing typologies for the low and middle income group. This theory is the basis for profit driven housing development by private developers in the peri-urban areas of Lagos.

The state-led housing development comes in the form of state intervention through industrial and housing development, and also to drive the growth of the suburb. Positive theory advocacy is what drives government-led housing. It emphasizes the role of housing quality as being factored by suppliers. It defines housing as an item of consumption to be supplied by government authorities. Housing is seen as socio-economic and environmental dimension. Family and individual's economic status is factored into the design of housing typologies. Family economic status determines the course of improvement of the housing units, which play a major role in the operation of the housing market for various levels of social groups (Waziri and Roosli, 2013).

Prior studies on housing typologies have been limited to urban Lagos and none has investigated the factors influencing housing typologies in the emerging Lagos peri-urban settlements. Understanding of the relationship between residents' socio- demography, housing initiative and housing relationship is needed in policy design of peri-urban housing development to achieve resident satisfaction. Therefore this study aims to analyse the typologies of housing in Lagos peri-urban areas and specifically seeks to investigate the factors to be put into consideration in achieving sustainable housing design and development.

\section{LITERATURE REVIEW}

Housing can be defined as building structure that a human lives in for meeting shelter and social needs (Abdul and Mahmud, 2012). Housing theories relate to Marxism, Radicalism and Liberalism. It is built on ideology and identity (Nassar, 2013). It is the social and spatial process in which building types are considered to be the convergence of social relation and spatial practices. There are three views to housing theories according to Soliman (2004). These is the Marxist theory or radical theory, Non- Marxist or Liberal Theory and Positive Theory. Under Marxist or Radical Theory, housing is seen in a capitalist social formation interest. It sees land as a precondition for housing production.

Non-Marxist/Liberal housing theory sees housing as one of the basic components that goes into the movement of development due to the elements, materials and services. This theory believes that housing is amongst the basic components that go into the movement of development, due to the elements, material, and services which actively relate to different activities; whether in industry, manufacturing, or services, as with various building materials, like iron, cement and timber; or infrastructure services, road networks and transportation (Tunstall et al., 2013). Financial capacity is the key. Positive theory relates to the socio-economic and environmental dimension of housing. Family and individuals economic status is the basic factor for determining housing priorities. Family economic status determines the course of improvement of the housing units, which plays a major role in the mechanisms of the housing market for various levels of societal groups (Waziri and Roosli, 2013).

Housing typologies refer to the distillation and classification of existing building types and urban forms in terms of social function and spatial efficiency. Housing typology defines members of the same household. It has evolved with technological innovations like the rise in the use of automobile and emergence of industrial building components. It changes depending on the needs of the developers (Law et. al., 2008). Housing typology is also based on need, scale, style and location. The patterns of housing investment, housing form, community services, settlement density and morphology are all relevant to the growth and pattern of peri-urban development. Housing classification is determined by society, affordability and legality in the form of government-led or private-led development and self-help housing. Housing in the peri-urban areas exists under three types of initiative and governance; self-built housing development, private developer - led housing and state-led housing development (Shen and Wu, 2013).

Housing typologies in the peri-urban areas, in terms of socio-spatial attributes are classified into commodity housing, single family house and mid-rise buildings. Each type of housing is characterised by different types of neighborhood. The commodity housing has co-renting options as it's unique attribute. It serves the poor migrants. It is called rooming apartment and is characterized by one apartment sub divided into numerous bedrooms. Other notable peri-urban housing typologies are single family bungalow, semidetached bungalow, rooming house, storied apartment building and duplex (Olotuah, 2006). Considering household size, the floor space per person for living and working is the primary determinant of housing typology. Investigation by Binns, Maconachie, and Tanko (2003) on housing typologies in peri-urban areas of northern Nigerian cities reveal presence of rooming house, detached house, compound house and blocks of flats. Rooming house is common to low income earners. It is adopted because of ease of design, minimal cost of construction and high return from rental. 
Socio-economic status has significant influence on the housing typology. It is notably affected by income status of the residents. Socio-cultural diversity and the socio-economic characteristics of the residents also greatly influence the physical characteristics of housing development in the periurban areas. Housing development in the peri-urban areas calls for consideration of the socio-economic attributes of the different income groups of the migrants, but this is not the case in most peri-urban housing developments (Shen and $\mathrm{Wu}, 2013$ ). Differentiating factors between the periurban resident groups could be through either socio economic factors, personal motivation for housing, housing choices preference and the resulting spatial differentiation. Non migrant groups are mostly home owners regardless of socio economic status. Rural migrants constitute the root of rental housing in the peri-urban areas. This class of people eventually settle in low cost private rental houses in the peri-urban areas (Wu and Zhang, 2012).

\section{THE STUDY AREA AND SCOPE OF STUDY}

Ibeju-Lekki local government area is the selected case study area for this study. Ibeju-Lekki (Figure 1) is one of the four local government areas outside Lagos Metropolitan Region. Within the past ten years, housing development has been on the increase to accommodate the overspill from central Lagos. The socio-demography comprise of multi-cultural and reasonably literate population. It has a land area of about 646 kilometers square, which equals to one quarter of the total land mass of Lagos State. Ibeju-Lekki has a population of 117,481 out of Lagos State's total population of 9,113,605, according to the National Population Commission 2006 census. The sample frame constitutes existing housing units in peri-urban settlements in IbejuLekki.

\section{METHODOLOGY}

The case study approach was applied by conducting a field survey of housing developments executed under different initiatives in the study area. Both qualitative and quantitative data was used in this study. Quantitative data was extracted from the questionnaire instrument, administered to household heads of randomly selected housing units, in purposely selected sixteen settlements in Ibeju-Lekki. Among the 370 questionnaires administered, a total of 366 good and complete questionnaires were retrieved from the study area. Badly completed questionnaires were considered as missing system in the analysis. The questionnaires were administered mostly during the weekend to ensure a high response rate. Descriptive analysis was conducted on the data to generate percentages and frequencies of respondents' socio-demography, housing initiatives, housing typologies. Test of correlation was conducted to determine the factors influencing housing typologies in the study area. Data analysis for this study was carried out using the Statistical Package for Social Sciences (SPSS) for statistical analysis of the quantitative data.

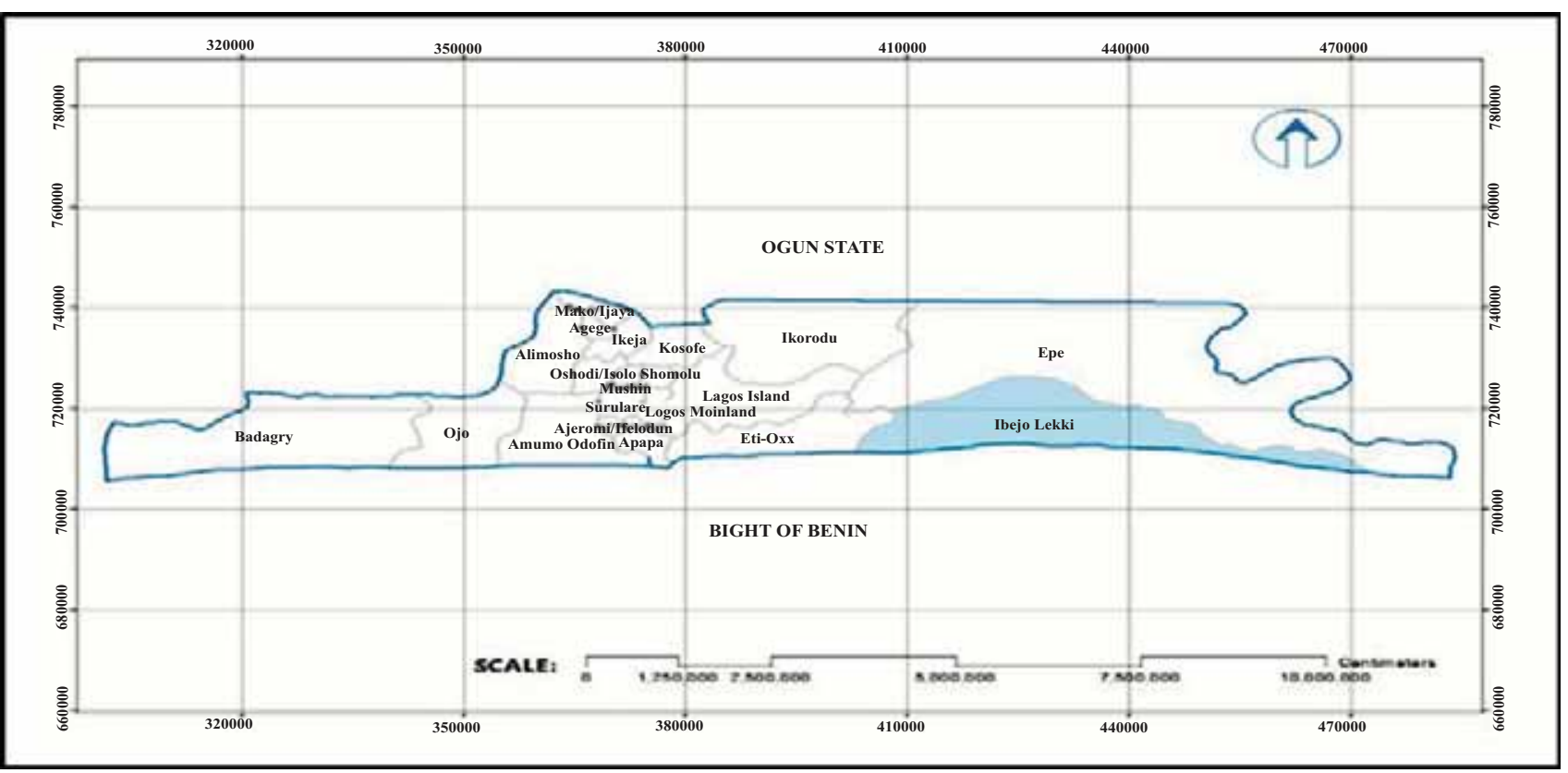

Figure-1: Map of Lagos State Showing Ibeju-Lekki.

Source: Field Survey (2017) 
Table-1: Housing Typologies in the Study Area.

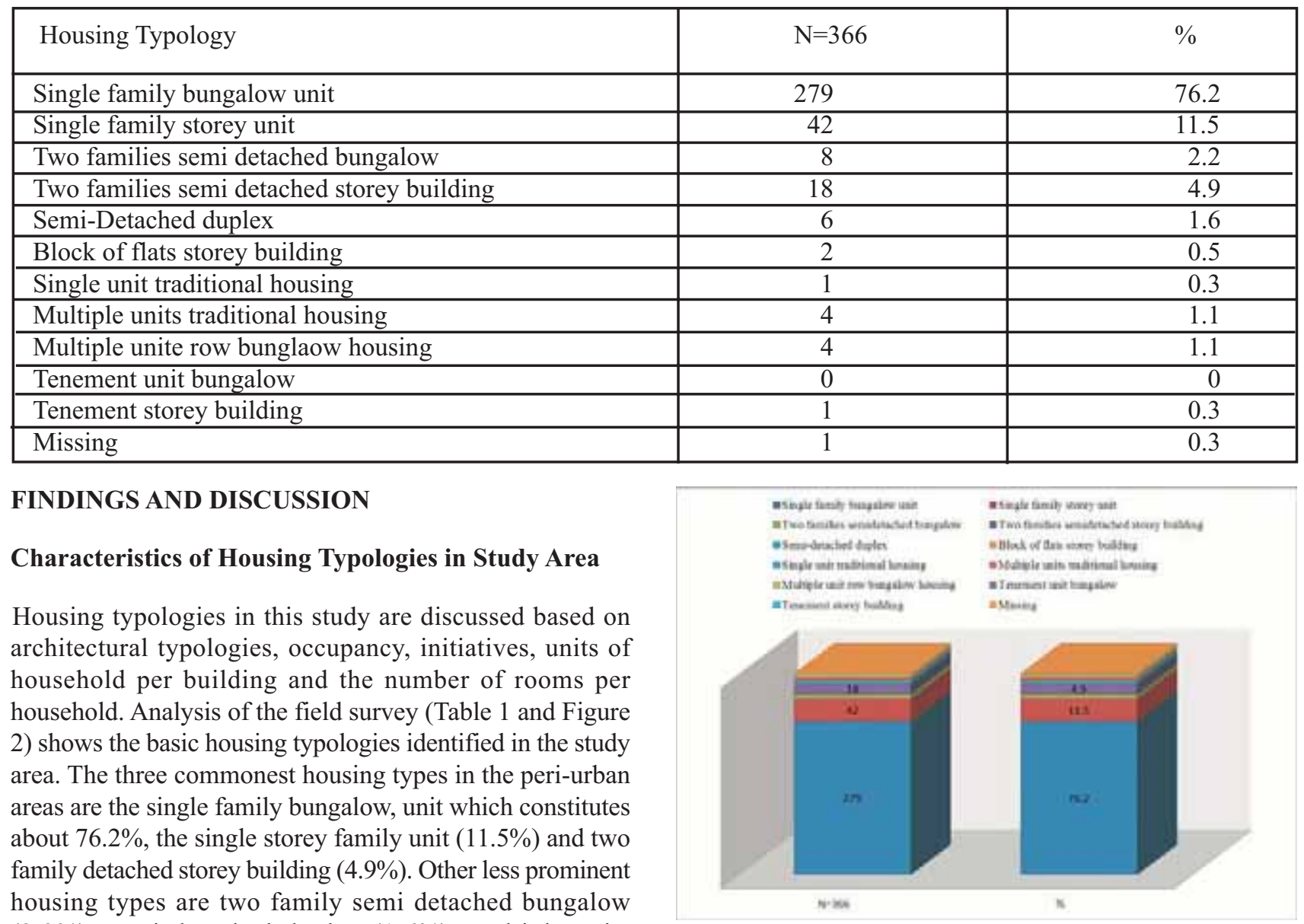
$(2.2 \%)$, semi detached duplex $(1.6 \%)$, multiple units traditional housing $(1.1 \%)$, multiple unit bungalow row housing $(1.1 \%)$, storey block of flats, single unit traditional housing $(0.3 \%)$ and tenement storey building $(0.3 \%)$.

\section{The Generic Classes and Types of Peri-Urban Housing Developments in the Study Area}

Three classes of housing development were identified in the study area. They are full family occupation, part family/part rented occupation and rental housing. Each class has different types of housing attached and also specific socio-spatial characteristics.

\section{Full Family Occupation}

Single family bungalow unit (Figure 3), is the most prevalent in both Ibeju-Lekki peri-urban settlements. It is predominantly owner occupied and not part rented. Analysis of the questionnaire shows the prevalence of this housing typology among the low income group, the Yoruba ethnic group, age group of 45-56 years and household size of 3-5 persons.

Figure-2: Housing Typologies in the Study Area.

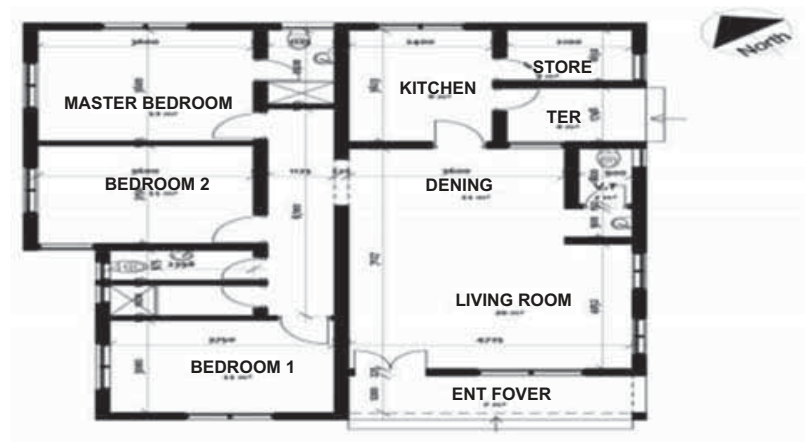

Figure-3: (Type 1) Typical Ground Floor Plan of a Single Family Bungalow Housing in the Study Area.

Some housing units are also single storey family housing (Figures 4 and 5) and occupied by a single family, especially among the polygamous families in the peri-urban. The single unit traditional housing is the regular housing unit among the natives, built is shared extended families and has usually poor quality building materials. 


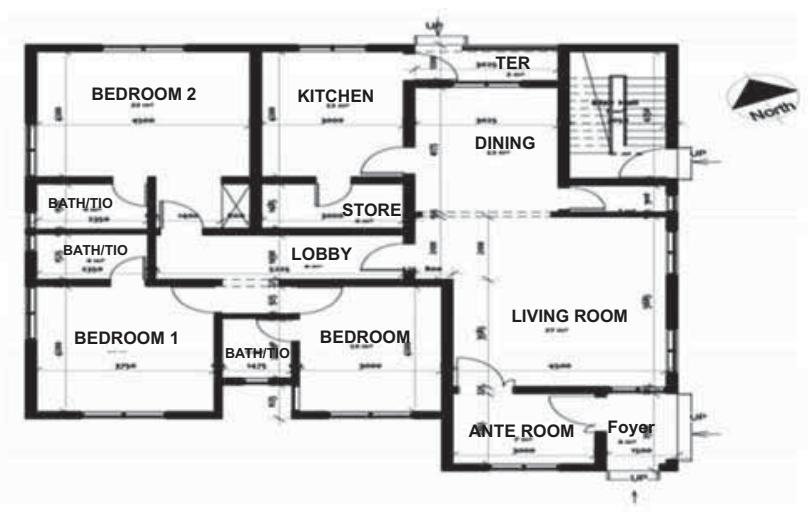

Figure-4: (Type 2) Typical Ground Floor Plan of a Single storey Family Housing Unit in the Study Area.

\section{Class B. Part Family Occupation/Part Rented}

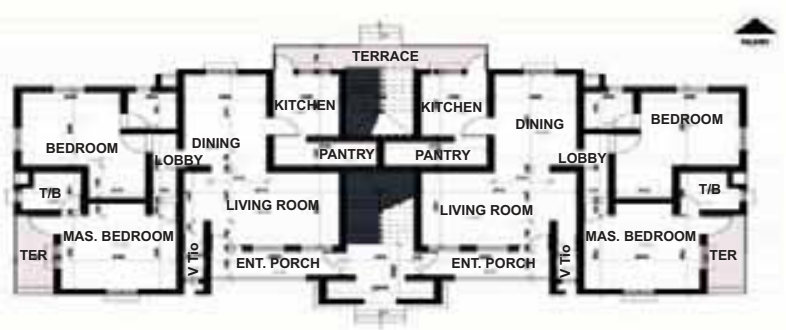

Figure-6: (Type 3) Typical Ground Floor Plan of Two Families' Semidetached Storey Housing Unit in the Study Area.

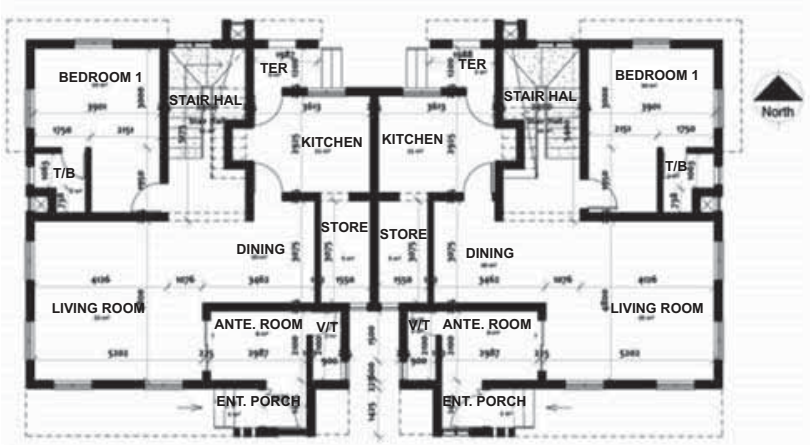

Figure-8: (Type 4) Typical Ground Floor Semi detached Duplex Housing Unit in the Study Area.

\section{Part Family Occupation/Part Rented}

The two families' semi detached bungalow housing (Figure $10)$ in the peri-urban area is partly owner occupied and partly rented out. Part of the building is usually occupied by the owner while the other wing of the bungalow is rented out for investment purpose, and also often for security purpose in areas of the peri-urban area that are far from the active city areas. Two families' semi detached storey housing unit (Figures 6 and 7), is like the two families semi detached house but has more floors. The owners usually occupy one unit of the whole house while the other wing is rented out. The semidetached duplex housing unit (Figures 8 and 9) is

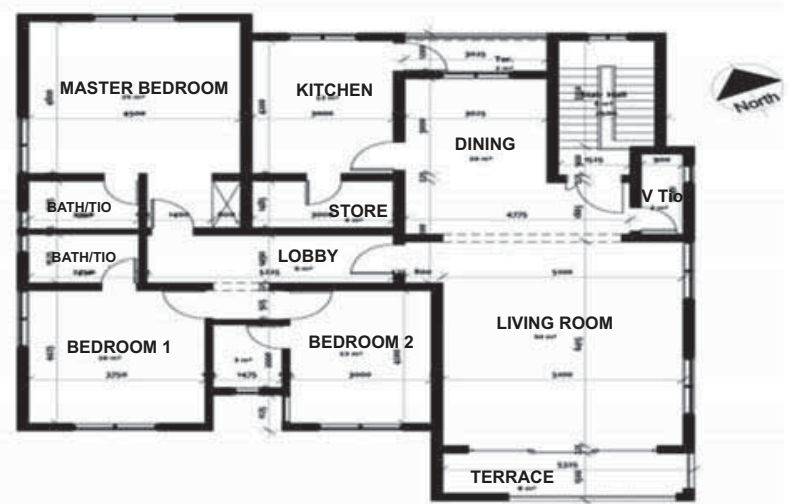

Figure-5: (Type 2) Typical First Floor Plan of a Single storey Family Housing Unit in the Study Area.

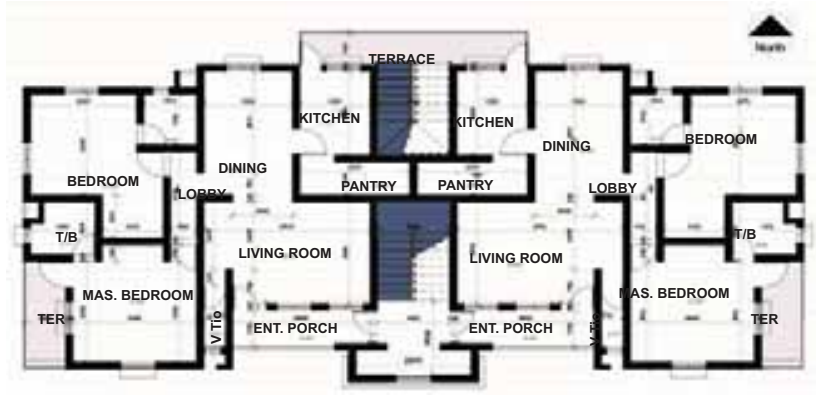

Figure-7: (Type 3) Typical First Floor Plan of Two Families' Semi detached Storey Housing Unit in the Study Area.

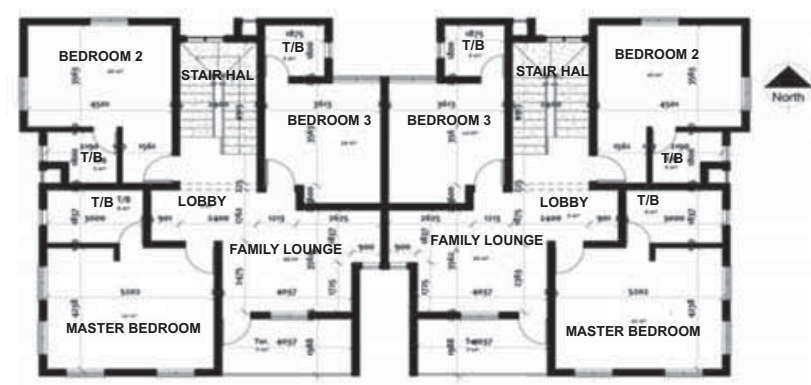

Figure-9: (Type 4) Typical First Floor Semi detached Duplex Housing Unit in the Study Area.

a two winged duplex building in which one unit is owner occupied and the other unit is rented out. This typology is common in developer-led housing and also amongst the middle income earners. Multiple units' traditional housing is built by association of extended family members, often having parts that are rented out while another part is occupied by the relatives. It is rather an inheritance housing in the peri-urban areas of Ibeju-Lekki.

\section{Rental Housing}

Block of flats (Figure 14) is a multi-family housing built mostly and purposely for profit and mostly not occupied by 


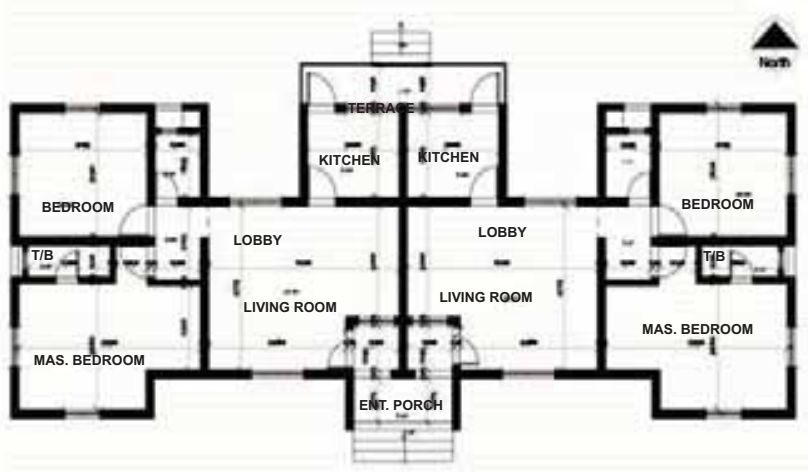

Figure-10: (Type 5) Typical Ground Floor Plan of Two Families' Semidetached Bungalow Housing Unit in the Study Area.

the owners. Tenement bungalow unit, commodity housing (Figure 11) is a single unit rental housing, sharing common sanitary facilities and built purposely for low income and the poor. Tenement storey building (Figures 12 and 13) is a bigger form of tenement housing. It has a ground and first floor but each floor, has rows of sanitary facilities communally shared. Finally, the multiple unit row housing (bungalow) consists of many household units on the same parcel of lands, built for rental purpose and not for the owner occupier.

\section{Architectural Design Typologies in the Study Area}

\section{Class A. Full Family Occupation}

\section{Socio Spatial Analysis of Housing Typologies in the Study Area}

There were three types of occupancy in the study area, full family occupation, part rented house occupation and full rental occupation (Table 2). The full family occupation was more prevalent in Ibeju-Lekki peri-urban settlements, (56\%) while part rented housing units were $44 \%$. Housing initiatives were mainly of three types in peri-urban settlements of IbejuLekki. Self-help housing was the commonest, constituting about $84.4 \%$ of the housing development. Private developers' initiatives were about $14.5 \%$ of the housing development in the peri-urban areas while government housing initiative was $1.1 \%$. The commonest household units per building in Ibeju-Lekki were $7-8$ units having $28.1 \%$ of the total households. Other types were 3-4 units $(22.1 \%), 8$-above units $(20.7 \%), 5-6$ units $(18 \%)$ and less than 2 units (10.9\%). The prominence of multiple units of household per building could be attributed to the preference for multiple storey buildings and investment-driven growth in Ibeju-Lekki periurban settlements.

According to the analysis of rooms per household, the commonest is $6-9$ rooms' household having $25.7 \%$. Others were 0 -2 rooms (11.2\%), 3-5rooms (24.9\%), 10-12 rooms $(19.9 \%)$ and more than 13 rooms $(15 \%)$.

\section{Class C. Rental Housing Development}

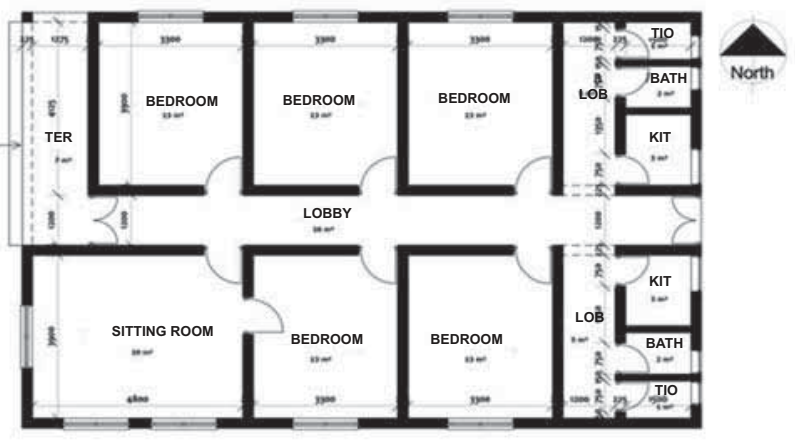

Figure-11: (Type 6) Typical Ground Floor Plan of a Families' Tenement Bungalow Housing Unit in the Study Area.

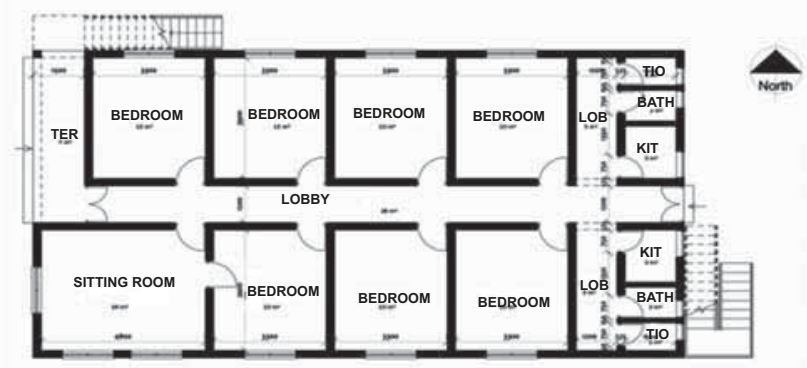

Figure-12: (Type 7) Typical Ground Floor Plan of a Single Storey Tenement Housing in the Study Area.

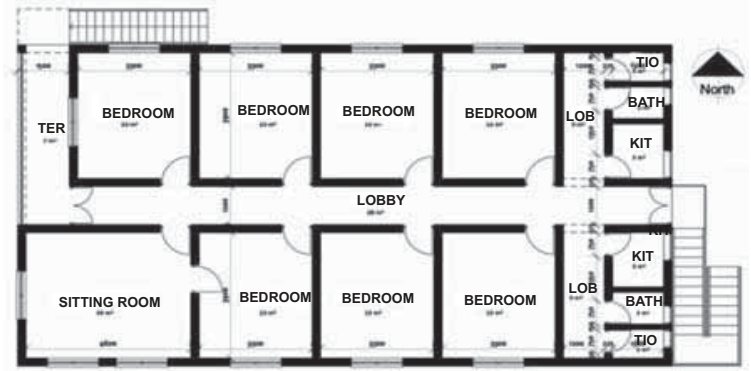

Figure-13: (Type 7) Typical First Floor Plan of a Single Storey Tenement Housing in the Study Area.

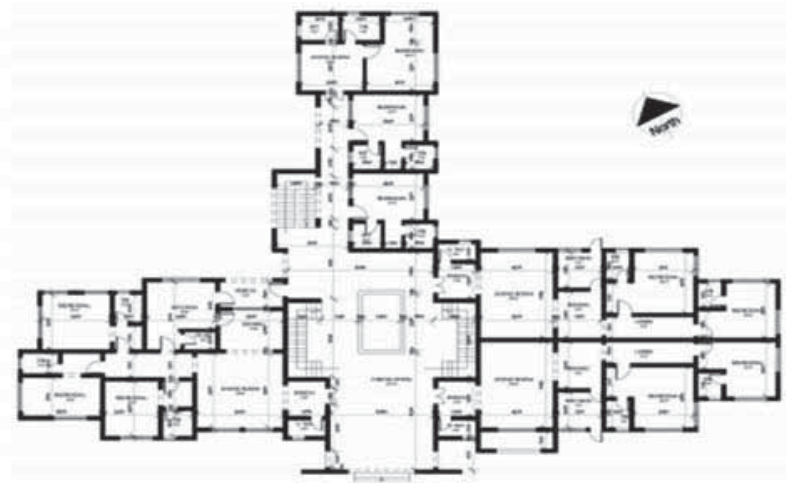

Figure-14: (Type 8) A Typical Ground Floor Plan of a Block of Flats Storey Housing Unit in the Study Area. 


\section{Residents' Socio-Demographic Characteristics}

Through the field survey presented in Table 3, there were five recognised household sizes in the study area. Household size of $1-2$ persons constituted $13.1 \%$ of the households, more than 13 persons constituted $3.3 \%$ and $10-12$ persons constituted $2.2 \%$. Household sizes of 3-5 persons was the commonest, having $55.2 \%$ of the respondents' population.
The other socio economic documentation revealed the following. The percentage of people with secondary school education was $30.1 \%$ and constituted the highest numbers. Highest level of literacy was the first degree, diploma and secondary school certificate constituting $32.7 \%, 20.8 \%$ and $34.3 \%$ respectively. $44.6 \%$ of the household heads earned above N150, 000 monthly. This was the predominant income group which was the high income group in the case study

Table-2: Analysis of Characteristics of Housing Units in the Study Area.

\begin{tabular}{|l|l|c|c|}
\hline \multirow{2}{*}{ Variable } & & $\mathbf{N}=\mathbf{3 6 6}$ & $\mathbf{\%}$ \\
\hline \multirow{5}{*}{ Occupancy } & Full Family Occupation & 205 & 56 \\
\cline { 2 - 4 } & Part Family Occupation/Part Rented & 161 & 44 \\
\cline { 2 - 4 } & Others & 0 & 0 \\
\hline \multirow{5}{*}{ Housing Initiative } & Self-Help Housing & 309 & 84.4 \\
\cline { 2 - 4 } & Private Developer/Cooperative & 53 & 14.5 \\
\cline { 2 - 4 } & Government Housing & 4 & 1.1 \\
\hline \multirow{5}{*}{ Rousehold Units per Building } & $0-2$ Units & 40 & 22.1 \\
\cline { 2 - 4 } & 3-4 Units & 81 & 18 \\
\cline { 2 - 4 } & $5-6$ Units & 66 & 28.1 \\
\cline { 2 - 4 } & $7-8$ Units & 103 & 20.7 \\
\cline { 2 - 4 } & 8-Above & 76 & 11.2 \\
\cline { 2 - 4 } & $0-2$ & 41 & 24.9 \\
\cline { 2 - 4 } & 3-5 Rooms & 91 & 25.7 \\
\cline { 2 - 4 } & 6-9 Rooms & 94 & 19.9 \\
\cline { 2 - 4 } & $10-12$ Rooms & 73 & 15 \\
\cline { 2 - 4 } & 13 and Above & 55 & 3.3 \\
\cline { 2 - 4 } & Others & 12 & 10.9 \\
\hline
\end{tabular}

Table-3: Socio-Economic Characteristics of the Household Heads.

\begin{tabular}{|c|c|c|c|}
\hline Variable & & $N=366$ & $\%$ \\
\hline \multirow{5}{*}{ House Size } & 1-2 Persons & 48 & 13.1 \\
\hline & 3-5 Persons & 202 & 55.2 \\
\hline & 6-9 Persons & 96 & 26.2 \\
\hline & 10-12 Persons & 8 & 2.2 \\
\hline & More than13 Persons & 12 & 3.3 \\
\hline \multirow[t]{6}{*}{ Literacy Level of the Household Head } & Postgraduate & 56 & 15.3 \\
\hline & BSc/Higher Diploma & 105 & 28.7 \\
\hline & Diploma & 62 & 16.9 \\
\hline & Secondary & 110 & 30.1 \\
\hline & Primary & 25 & 6.8 \\
\hline & None & 8 & 2.2 \\
\hline \multirow{3}{*}{$\begin{array}{l}\text { Monthly Income of Household Head } \\
\text { (Naira) }\end{array}$} & Low Income N25,000-N50,000 & 133 & 36.3 \\
\hline & Middle Income N50,001-N150,000 & 70 & 19.1 \\
\hline & High Income N150,001-Above & 163 & 44.6 \\
\hline \multirow[t]{5}{*}{ Respondents' Ethnic Group } & Yoruba & 263 & 71.9 \\
\hline & Hausa & 6 & 1.6 \\
\hline & Ibo & 70 & 19.1 \\
\hline & Others & 27 & 7.4 \\
\hline & Total & 366 & 100 \\
\hline
\end{tabular}


area. The low income group earned between $\mathrm{N} 25,000.00$ to N50,000.00 and constituted $36.3 \%$ while the middle income group earned N50,000.00- N150,000.00 land constituted $19.1 \%$. The Yoruba ethnic group constituted the largest portion of the population in the study area, at $71.9 \%$ while the Hausa tribe was the least represented.

\section{Factors Influencing Housing Typologies in the Study Area}

\section{Impact of Housing Initiative on Housing Typology}

The correlation analysis presented in Table 4 shows that there was a significant relationship between housing initiatives and housing typology in the study area $(0.200 * * \mathrm{P}<0.01$ in Ibeju-Lekki). This signified that there is a relationship between housing initiatives and typologies in the study area.

\section{Impact of Residents'Socio-Demography on Housing Typology}

The test of correlation between housing typologies and respondents' socio-demographic and economic attributes (Table 5) showed that income is the only attribute having a significant relationship with housing typologies in the study area $(-0.205 * * \mathrm{P}<0.000)$. Therefore, housing typologies were influenced by respondents' socio-demography.

\section{CONCLUSION}

There were ten different housing typologies identified in the study area each having distinguishing socio-spatial attributes. Generic classes of housing typologies observed in the study area were full family occupation, part family/rental and full rental housing. Housing occupancy in Ibeju-Lekki shows that full family occupation was $56 \%$ while part family and part rented occupancy were $44 \%$. The commonest housing type in Ibeju-Lekki was the single family bungalow housing and single family storey building constituting $76.2 \%$ and $11.5 \%$ respectively. The commonest type of households units per building were the 7-8 units, and 0-2 grouping was the least. The commonest rooms per household in IbejuLekki housing were 3-5 rooms. To determine the factors influencing housing typologies in the study area, a test of correlation was conducted which showed that housing typology was affected by socio-demography of the residents. Major socio-economic attribute that affected housing typology in the study area was income with a p-value of 0.000 and Pearson correlation of -0.205 . It showed a significant negative linear relationship with housing typology. The implication of this was that the less the income, the less the quality and standard of housing typology that can be assessed. A test of correlation also showed that housing typology in the study area was affected by the housing initiatives under which the building construction was executed. It can be concluded that the construction of the different housing typology in the study area was a response to the existing housing policy and residents' socio-economic demography.

\section{RECOMMENDATION}

In order to improve the quality and delivery of housing in the peri-urban areas of Lagos, it is recommended that there should be an inclusion of the end users in the design stage,

Table-4: Test of Correlation Between Housing Typologies and Housing Initiatives.

\begin{tabular}{|l|l|c|l|}
\hline Variables & Pearson Correlation & P-Value & Inference \\
\hline $\begin{array}{l}\text { Housing Typologies } \\
\text { and Housing Initiatives }\end{array}$ & $0.200 * *$ & 0.000 & $\begin{array}{l}\text { There is a Significant } \\
\text { Correlation Between the } \\
\text { Two Variables }\end{array}$ \\
\hline $\begin{array}{l}* * \text { Correlation is Significant at the } 0.01 \text { Level (2-Tailed). } \\
\text { List wise N=366. }\end{array}$ & & \\
\hline
\end{tabular}

Table-5: Correlation Between Housing Typologies and Respondents' Socio-Demography.

\begin{tabular}{|l|l|c|c|l|}
\hline Test Variables & Sub Variables & Pearson Correlation & P-Value & Inference \\
\hline $\begin{array}{l}\text { Housing Typologies } \\
\text { and Respondents }\end{array}$ & Income & $-0.205^{* *}$ & 0.000 & $\begin{array}{l}\text { Significant negative } \\
\text { Linear Relationship }\end{array}$ \\
\cline { 2 - 5 } $\begin{array}{l}\text { Socio-Economic } \\
\text { Attributes }\end{array}$ & Literacy Group & 0.043 & 0.410 & No Significant Correlation \\
\cline { 2 - 5 } & Ethnic Group & 0.061 & 0.242 & No Significant Correlation \\
\hline $\begin{array}{l}* * \text { Correlation is Significant at the 0.01 Level (2-Tailed). } \\
\text { List wise N=366. }\end{array}$
\end{tabular}


especially in those projects that target low and middle income groups, to help achieve appropriate housing delivery strategy by housing providers, in terms of the provision of an efficient and user responsive housing units. Furthermore, post occupancy evaluation should regularly be carried out in any housing initiative outside of self-help initiatives, to determine their efficiency and suitability for the peri-urban settlements. This will enhance performance standard in other housing projects being executed in the city.

\section{REFERENCES}

Abdul, A. I., Mahmud, B. M. J., 2012, "End-users Participation Approach towards Effective Housing Occupancy in Malaysia: A Review", British Journal of Arts and Social Sciences, 8(1), 183-197.

Binns, J; Maconachie, R; Tanko, A., 2003, "Water, Land and Health in Urban and Peri-urban Food Production: the Case of Kano, Nigeria", KANO water LDD revised, 14(5), 431-444.

Gough, K. V; Yankson, P. W., 2000, "Land Markets in African Cities: The Case of Peri-urban Accra, Ghana”, Urban studies, 37(13), 2485-2500.

Law, D., Rogan, D., Zoghaib, D; Zarges, J., 2008, “Emerging Typologies”, In: Emerging Typologies and Density, London School of Economics, London, 58-86.

Nassar, D. M., 2013, Theories of Housing, Architectural Engineering Department, Faculty of Engineering, Pharos University. Olotuah, A. O., 2006, "Housing Quality In Suburban Areas (An Empirical Study of Oba-Ile, Nigeria)", Dimensi Teknik Arsitektur, 34(2), 133 - 137.

Shen, J; Wu, F., 2013, "Moving to the Suburbs: Demand-side Driving Forces of Suburban Growth in China", Environment and Planning, 45(8), $1823-1844$.

Simon, D., 2008, “Urban Environments: Issues on the Peri-Urban Fringe”, Annual Review Environmental Resources, 33, 167-185.

Soliman, A., 2004, A Possible Way Out: Formalizing Housing Informality In Egyptian, Lanham, University Press of America, Inc; MD USA.

Tunstall, R. et al., 2013, The Links Between Housing And Poverty: An Evidence Review, Joseph Rowntree Foundation, York.

Waziri, A. G; Roosli, R., 2013, "Housing Policies and Programmes in Nigeria: A Review of the Concept and Implementation", Business Management Dynamics, 3(2), 60-68.

Wu, K. Y; Zhang, H., 2012, "Land Use Dynamics, Built-up Land Expansion Patterns, and Driving Forces Analysis of the Fast-growing Hangzhou Metropolitan Area, Eastern China (1978-2008)", Applied Geography, 34(1), 137-145. 